\title{
The Vicious Cycle in the Bolsa Família Program's Implementation: Discretionality and the Challenge of Social Rights Consolidation in Brazil
}

\section{Flávio Eiró ${ }^{1}$}

Published online: 25 June 2019

(C) The Author(s) 2019

\begin{abstract}
This article aims to consider conceptions of the Brazilian conditional cash transfer Bolsa Família Program as elaborated by both those responsible for its implementation and its beneficiaries in Northeast Brazil. Most innovative in this study is the adoption of the program's municipal social workers, who are responsible for the implementation of the program, as the main observation point, by conceptualizing them as street-level bureaucrats. The research is based on ethnographic fieldwork that took place between 2013 and 2015, for a total of six months, combined with in-depth interviews with the program's beneficiaries in a middle-sized municipality of the State of Ceará. Social workers enjoy a range of discretion that directly affects the distribution of benefits. Their efforts to better apply what they see as scarce resources are embedded in their representations of poverty - separating "deserving" from "undeserving" poor-generating insecurity among beneficiaries. By doing so, beneficiaries' understanding of the program as a social right is compromised, which is reinforced by a fragile legal status enjoyed by the Bolsa Família and ambiguous bureaucratic procedures.
\end{abstract}

Keywords Poverty Street-level bureaucracy $\cdot$ Social work $\cdot$ Conditional cash transfer $\cdot$ Northeast Brazil

Flávio Eiró

f.eiro@maw.ru.nl

1 Department of Anthropology and Development Studies, Radboud University, Nijmegen, The Netherlands 


\section{Introduction}

The Brazilian Conditional Cash Transfer (CCT) ${ }^{1}$ Bolsa Familia Program (Family Grant, BFP) is widely considered a successful case of anti-poverty action, with its existence rarely challenged in Brazilian politics (Hall 22). The program is seen as a departure from the usual development of Brazilian social assistance, focusing, as it does, on "rights" and "state responsibility" (Yazbek 66), as opposed to emergency- and charity-related food and goods distribution, which have been the norm (Almeida 1). The discussion around the "rights" dimension of the program is often developed in two complementary lines. The first stresses its impersonality and bureaucratic performance in order to challenge clientelist accusations (Bohn 6; Fenwick 19; Sugiyama and Hunter 60). The second interprets it as one step in a larger process of strengthening the goal of social assistance, which is to provide a guaranteed minimum income based solely on citizens' rights (Barrientos 4), as proposed by universal basic income advocates (Caillé 9; Suplicy 61). These lines fail to understand how empirical and localized limitations in the implementation of CCT programs impact how beneficiaries construct them as social rights interventions, regardless of whether or not they are a constitutional right or a government program - to which citizens expect equal access and fair treatment. It is in this context that this article aims to consider conceptions of the Bolsa Família Program as voiced by both those responsible for its implementation and by its beneficiaries.

It is now well established that "the expansion of social rights has been accompanied by the rise of large-scale welfare state bureaucracies that determine the content of these rights through the programs and services they control" (Hasenfeld et al. 24, 397). Building on this line of thought, the approach I used in this research was to focus on Bolsa Família's municipal social workers, viewing them as street-level bureaucrats (Lipsky 38) responsible for the implementation of the program-bureaucrats whose power can shape social policy, effectively transforming the citizenship rights of the poor. More specifically, as I will demonstrate, social workers enjoy a range of discretion when determining a family's level of poverty, and this directly affects the distribution of benefits. Many authors have drawn on Lipsky's conceptualization of social workers as street-level bureaucrats (e.g., Evans and Harris 18; Hasenfeld 25; Rice 52) and, in France, a specific field of studies has emerged called sociologie du guichet (Dubois 15; Siblot 58; Spire 59; Weller 65), in which the reception counter has become a symbol of regulation and social domination over the poor.

Social workers' actions are determined by their own interpretations and representations of the Bolsa Família and the poor, and one of my primary focuses in this paper is on how social workers' discretionary practices influence their perceptions of people in poverty, particularly their right to benefit from the program. My core argument is that BFP's social workers' informal practices in allocating what they see as scarce resources are embedded in their conceptions of poverty. The separation of "deserving" from "undeserving" poor, in turn, shapes how they implement the program and exacerbates a sense of insecurity among beneficiaries. Beneficiaries' understanding of the BFP as a social right thus becomes compromised, and this is reinforced by the fragile legal status and ambiguous bureaucratic procedures evident in the program.

\footnotetext{
${ }^{1}$ CCTs are anti-poverty programs that directly distribute monetary benefits to target families that are under an established poverty line. Benefits are conditional on beneficiaries' actions, which typically involve education and health.
} 
The idea that the Bolsa Família's implementation process plays a significant role in the outcome of the program is not new in Brazil. Bichir (5) and Oliveira (44), among others, have drawn on the street-level bureaucracy theory to analyze the reproduction of inequalities in policy implementation in the country (see, too, Lotta 39; Pires 51, 50). However, to my knowledge, no academic work has combined both the street-level bureaucracy approach and the focus on social rights consolidation in the Bolsa Família, and this is the first study to highlight the participation of the program's social workers in shaping policy implementation. The literature on the effects of CCTs worldwide is abundant, but this field of study has yet to embrace implementation studies and take a closer look into the relationship between agents and beneficiaries, and the consequences this relationship has in transforming policies. By drawing on ethnographic fieldwork, this article is the first to focus specifically on implementation agents' discretion in CCT programs.

Other similar studies in Brazil have found opposing results to those I present in this article (i.e., Bohn 6; Fenwick 19; Hunter 29; Leao Rego and Pinzani 37; Sugiyama and Hunter 60). They highlight the positive outcomes of the Bolsa Família regarding recipients' citizenship. Their central argument is that "the daily fulfillment of basic needs is a precondition for feelings of social inclusion" (Hunter and Sugiyama 28, 835). Although my research is not aimed at disqualifying such studies - and offers no data to do so-it does offer evidence of limitations in this process. As will become clear through my analysis, it is the interaction between different factors that limits the BFP's potential to expand the poor's citizenship, factors that include the fragile status of the program, discretionary practices, and class relations within the program's implementation. What allowed me to see such factors in play, factors that others might have missed, was the long-term empirical ethnographic fieldwork that I conducted at a local BFP office.

This article contains four sections. The first describes the Bolsa Família, focusing on the program's legal status and the waiting list procedure. ${ }^{2}$ The second presents the methodology and provides a description of the city where the research took place, here named Angico. The third zooms in on the social workers responsible for the program's implementation and their work environment, highlighting their perceptions and representations of the poor and how they incorporate these into their daily activities. The final section addresses how social workers' practices impact beneficiaries' views of the BFP, giving rise to a vicious circle that reinforces perceptions of poverty and insecurity among beneficiaries.

\section{The Bolsa Família Program}

The Bolsa Família Program is the largest CCT program in the world in terms of the number of people it assists, which currently stands at around 14 million families-about 50 million people, a quarter of Brazil's population. It targets people below both the poverty and extreme poverty line, defined by a monthly household income up to $\mathrm{R} \$ 170$ and $\mathrm{R} \$ 85$ per capita respectively. ${ }^{3}$ In 2003, the BFP was created by a presidential decree and, on January 9, 2004, it became a federal law (law number 10,836). The program's legal basis does not imply that

\footnotetext{
${ }^{2}$ Other authors have made a full description of the program (Hallmann 2015), its creation and development (Hall 21). The literature on the BFP's impacts is abundant, such as on poverty and inequality reduction (SánchezAncochea and Mattei 55) and gender equality (de Brauw et al. 12).

${ }^{3}$ Values for 2018, for a minimum wage of 954 Brazilian reais (BRL) (US\$ 1 = BRL 4.00 on May 13, 2019).
} 
access to it is an established right for qualifying applicants. The BFP was conceived as, and remains, a targeted program: in 2008 the government stated, "The granting of BFP benefits has a temporary nature and does not constitute an acquired right. The eligibility of families to receive such benefits should be mandatorily reviewed every 2 years" (Article 21 of Decree 6392, own translation).

If it was an "acquired right," access to Bolsa Família would be unrestricted to those qualifying for the program. Instead - even though the government itself has promoted the program as a "social right" (Hunter and Sugiyama 27), and some even suggest that the widespread political support the program enjoys has changed its de facto status (Ávila 3)the BFP remains a federal government program based on quotas per municipality. This means that the government can suspend or change the rules of the program at any moment. Besides being a neoliberal budgetary measure that targets social investment (Lavergne and Beserra 36), this legal condition enables the existence of conditions that beneficiaries must meet in order to maintain receipt of benefits. However, the program is also based on laws and defined rules. Whether it is a constitutional right or a government program does not change the equal and fair treatment the population expects to have when accessing it.

The Bolsa Família is nevertheless a fundamental part of the poor's citizenship, here understood not only as the formal rules that structure the relationship between citizens and the state, but as all of the interactions, formal and informal, that occur in everyday life (Desforges et al. 13; Koster 33), as well as the imaginations of the state that emerge from them (Kruper and Nugent 35; Lund 40). In this context, the BFP represents, for many, the only positive exchange with the state as an entity that is separate from local politicians. Unlike most previous social assistance programs, the BFP is federally funded and regulated, and monetary benefits are distributed directly to families (they can be withdrawn from ATMs). Although widely described as a "favor" (Ávila 3), a few beneficiaries described the program as the "recognition of their struggles by the government," or as a return of the taxes they pay, or even as compensation for the many public services they know they are supposed to receive or have access to, but which they see as insufficient (Eiró 16).

The program's so called "conditionalities" are that children go to school and are vaccinated, and that pregnant women have regular medical check-ups. Depending on family composition, the benefits vary from $\mathrm{R} \$ 39$ to $\mathrm{R} \$ 372$, and are designed to lift families above the poverty line. ${ }^{4}$ Indeed, since 2012, legislation was passed allowing the maximum limit to be exceeded, if necessary, in order to ensure families rise above the extreme poverty line. ${ }^{5}$ By the end of 2017 , 13.9 million households were benefiting from the BFP, with an average benefit value of $\mathrm{R} \$ 179$.

Nominated cardholders responsible for the family benefit are, whenever possible, womena deliberate choice related to intra-family women's empowerment, and the moral expenditure of family resources, regarding which there is a perception that women are more rational and will, for example, prioritize child welfare (Santos 56). This carries a heavy normative and controlling dimension (Lavergne and Beserra 2006), as has been highlighted by social workers administering personal social services (Handler 23).

\footnotetext{
${ }^{4}$ In Brazilian social assistance, family is "the nuclear unit, possibly expanded to other individuals who have ties of kinship or affinity with it, forming a domestic group, living under the same roof and that sustain itself with the contribution of its members" (Federal Law 10, 836, January 9, 2004). Thus, in this article, "family" and "household" are used interchangeably.

5 The "Benefit for Overcoming Extreme Poverty" is part of the "Brazil Without Poverty" initiative (Brasil Sem Miséria), a broader umbrella plan under which the BFP falls.
} 
Since its creation, BFP's rules have been through a number of reforms that have increased its complexity not only regarding the value and composition of benefits, but also the criteria for family eligibility (Osorio and Soares 46). Beneficiaries' benefits are calculated automatically, according to predefined rules, and it is difficult for either beneficiaries or municipal staff to predict the amount.

Although a federal program, the Bolsa Família is implemented by municipalities, which run local offices and are responsible for their staff. Federal resources are exclusively designated to infrastructure investment. The BFP's main implementation steps are: (1) the federal government allocates quotas to municipalities based on an estimated number of poor families; (2) municipalities proceed to register potential families in a centralized database - the Unified Registry (Cadastro Único) — controlled by the Ministry of Social Development (MDS) ${ }^{6}$; (3) files are processed automatically to determine families' eligibility and the value of their benefit; (4) benefits are transferred directly to the families via a personal magnetic card; (5) the MDS sporadically checks for irregularities, cross-checking with income taxes and labor databases, and families presenting with irregularities will have their benefit blocked or suspended and will be flagged to municipalities; (6) municipal offices follow-up on beneficiaries, updating cadastral information, checking compliance with conditions, and verifying any irregularities. Local offices can temporarily block benefits in cases of suspicion of declared false information. The family is notified that the benefit has been blocked at the next attempt at cash withdrawal, but is not given a reason.

Although municipal quotas are defined by the estimated number of people in poverty - and are thus supposed to cover all poor families - they cannot reflect the complex realities of such families' income challenges, such as work instability, income fluctuations, and intermunicipality migration flux. Such factors are acknowledged in the program's flexibility, in that benefits are not automatically canceled for families that fall out of the targeted profile. Once its benefit has been blocked, a family has six months to contact the local office before the benefit is definitively canceled. The measures for protecting these beneficiaries, who might fall into poverty once again, contribute to a coverage problem. Even during the times when the BFP coverage was close to $100 \%$ of poor families - and recent cuts in the program and a concomitant increase in poverty levels in the country suggest this is not the current situationthe quota system contains an inherent problem: As quotas are allocated based on estimates of people in poverty, and if we suppose that these estimates are accurate, each "non-poor" family receiving benefits represents one "poor" family that does not. Although scarcity of resources in the BFP is not as great as in most social policies, the quota system generates waiting lists for places that only become available when beneficiaries exit the program (voluntarily or not), or when the quotas are updated.

\section{The Research}

The analyses developed in this article are based on ethnographic research conducted in a city, which I here call Angico, in one of the largest municipalities of Ceará state, in three periods spread over three years (2013-2015), for a total of six months. Angico is a medium-size city (officially defined in Brazil as having a population of 100,000-500,000 people), in the hinterland of Northeast Brazil, the Sertão or Brazilian Semiarid, a region in which a great

\footnotetext{
${ }^{6}$ In 2019, the ministry was renamed by the Bolsonaro administration to "Ministry of Citizenship."
} 
deal of the country's poverty and Bolsa Família beneficiaries are concentrated (Campello and Neri 10). Situated in a predominantly rural area, Angico's recent process of economic development and urbanization is illustrative of the transformations occurring not only in Northeast Brazil, but in several regions around the country.

The ethnographic research relied mostly on the direct observation of the daily activities of the BFP municipal office, where almost all activities concerning the implementation of the program are developed. The focus of observations was on the interactions between social workers and beneficiaries. During those months, I constantly followed social workers in their daily work, accompanying them on house visits, and being present during interviews with beneficiaries in the BFP office. During house visits, social workers introduced me as an "intern," since internships were common for social workers in training. In the Bolsa Família office, I was rarely introduced, and I became one of many people ensuring that those encounters always lacked privacy.

Noting the problematic nature of the relationship between beneficiaries and the BFP social workers, it became clear that my observations needed to extend to other social assistance institutions. For this reason I widened my study to include the Social Assistance Reference Center (CRAS) office. I made contact with the CRAS through a social worker who had been working in the BFP at the time of my first field trip, but later moved to the CRAS. She invited me for a visit. As the CRAS is considered to be the "contact point" for all social assistance services, its social workers perform some activities related to the implementation of the BFP, and are in constant contact with the program's social workers. I obtained permission to conduct research from the coordinator of the unit, and started to follow the daily life of the 10 or so social workers who worked there. This particular CRAS office- one of 10 in Angico-was located in the city's poorest neighborhood. Of all the offices, it had the greatest number of employees and the largest population to cover.

I believe that my social position in the field had different impacts on the two groups (social workers and beneficiaries) with whom I conducted research. My interactions with social workers from both offices were friendly. Even if I was usually the only man aroundalthough not white - it was clear from my appearance and accent that I came from the southern part of Brazil, and I was probably perceived to come from a higher class than the social workers, despite the fact that we were all roughly the same age and shared similar interests. These social workers were used to hosting researchers (albeit for shorter periods than I stayed), and many of them were interested inpursuing some kind of post-graduate study. As I had told them I was conducting my PhD research, this became the most important subject for small talk during our first meetings. They were generally proud of their work, and had no reservations sharing their knowledge with me. As I was not a social worker, I was treated (rightly) as ignorant regarding the nature of their work, and therefore in need of constant lecturing on the subject—which gave me invaluable insights.

Regarding the beneficiaries' interviews, my approach to gain their trust was two-fold: First, I emphasized the educational aspect of my work, and that I wanted to learn, from their experiences, things about the Bolsa Família that are impossible to learn from far away. Second, I described to them some of my observations from the BFP office, looking for reactions to events that they may not have mentioned spontaneously. My fear was to be seen as a social worker, or as someone who could directly affect their benefits. However, coming from outside the region played to my advantage: they hoped my work could help improve the BFP. By echoing their positive perceptions of the program (on which they would always focus), I tried to avoid them feeling I was judging them in any way. 
Beyond direct observations, the other techniques I used were: (1) repeat interviews and conversations with a total of 18 social workers (see appendix) directly involved in the Bolsa Família's activities, or who had performed this work in the last few years; (2) in-depth interviews with 35 BFP beneficiaries (see appendix), focusing on the beneficiaries' perceptions of the program.

I interviewed the beneficiaries, without the social workers, in their homes. The interviews were 30-90 minutes long. Respondents were selected using a snowballing technique, with four different starting contacts who had been introduced to me by social workers. They then indicated neighbors or friends that were also BFP beneficiaries. All interviewees in this study signed an informed consent term of participation that guaranteed them complete anonymity.

The analyses conducted in this article were inspired by the tradition of implementation studies, which aims at highlighting one of the forces that determines policy impactacknowledging that not all problems within policies are a result of insufficient planning or of the inadequacy of the program itself (Van Meter and Van Horn 63). Furthermore, this study is empirically rooted in what has been called an "institutional ethnography," a feminist method of inquiry that focuses on how institutions organize people's everyday lives (Cookson 11; Smith 2005). By making use of this radical inductive approach, my goal was first to see the BFP through social workers' eyes, and later to discuss their practices with beneficiaries. Rather than merely combining these perspectives, I also draw on the symbolic interactionism tradition (Goffmann 1974), and the micro-sociological approach to the study of street-level bureaucracies (Dubois 15).

\section{Bolsa Família Program's Social Workers as Street-Level Bureaucrats}

This article demonstrates how social workers incorporate representations of poverty in their daily activities, and how these representations shape the ways in which they implement the Bolsa Família. Although this incorporation might not be an intentional action, it is motivated by the need to deal with a perceived scarcity of resources and a consequent intention to avoid fraud at all costs, resulting is a "system of bureaucratic rationing" (Hasenfeld et al. 24). Thus, in their contact with beneficiaries, social workers constantly engage in a moral assessment of household expenses and beneficiaries' behavior in order to separate them into two categories: deserving or undeserving of public aid. As demonstrated later in the article, this practice is part of a vicious circle that increases beneficiaries' insecurity towards the program and therefore the chances of "suspicious behavior" that will make social workers act more strictly. It is worth mentioning that to blame the poor for their condition is not a new phenomenon, nor is it something exclusive to Brazil. Indeed, as Katz (32, xiii) wrote, the perceived moral standing (or lack thereof) that poor people exhibit has been "the oldest and most enduring answer to the question, what kind of a problem is poverty?" This relates directly to the differentiation between deserving and undeserving poor, a judgment conducted by most religions and thus present since the beginning of public policies to alleviate poverty.

I analyze the discretionary practices social workers employ, using the street-level bureaucracy theory developed mainly by Michael Lipsky (38). Lipsky's core argument is that streetlevel bureaucrats such as social workers should be acknowledged and conceptualized as the last link in the policy-making chain, since it is only in bureaucrats' interactions with clients that public policies "come to life." According to Lipsky, agents' behavior is influenced by two factors: organizational context and intrinsic cognitive-emotional utility functions. The latter 
concerns not only the individual disposition, but also group practices and values. The organizational context gives the material both structure and limitations-usually limited resources - that will influence an individual's perception of the discrepancy between the policy's goals and the means of its application.

Other authors have observed that the adaptation of policies has occurred specifically in the interaction between bureaucrats and citizens (Warin 64). In the particular case of social workers, Rice (52) suggested that the combination of such factors determines whether streetlevel bureaucrats rigorously apply, creatively adapt, or undermine the program goals in their interaction with beneficiaries. In that context, Maynard-Moody and Musheno (41) found that street-level bureaucrats classify clients into social or professional categories in order to simplify their work. They describe how social workers concentrate their efforts on clients they view as worthy of investment. We also know that perceptions of deservingness is contingent on the personal characteristics of implementation agents, particularly gender and race (Jilke and Tummers 31).

In social policy, discretion is commonly planned or expected. In the Bolsa Família case, it is no different: Even if the program relies solely on self-declared household income to determine the allocation of benefits, social workers are expected to correctly calculate the average monthly income with beneficiaries. When households are flagged to the municipal officedue to any number of reasons such as irregularities, procedural tasks, or random testingsocial workers proceed to verify irregularities, and this may, or may not, cause them to temporarily block the benefit. They can do this if there are indications that the family is not eligible for the program. In one social worker's words (Ana, 25), using the "sensitivity" acquired in their training to reach a decision, social workers ask themselves: "Is the household eligible to receive the benefit?" and "Are the values provided correct?" These questions are motivated by what social workers often described as the "fundamental problem" of the Bolsa Família: the self-declaration of household data (income included), which is not supposed to be contested by local social workers. However, in a context of poverty, the majority of beneficiaries have informal or seasonal work, for which they cannot provide proof of wages. Social worker Paula, 23, explained her view on the matter:

[The beneficiaries] know they can say whatever they want and we are obliged to believe them. At least initially. Later we find our ways, but it can take months. If we had enough resources to register all the families at their place, it would be different. In the end, this

job is to swim against the stream.

The way social workers view these encounters testifies to what Weller (65) identified as the latent tension of such a relationship, marked by a conflict of discourses. Before exploring the "ways" found by them to "fix" such problems, and in order to understand the frames of reference used by social workers when facing these situations, it is important to first understand who they are. The main goal here is to locate street-level bureaucracy in the social context into which it is inserted. Adopting a critical approach to the study of policy delivery must consider the social positions of individuals (Bourdieu 7) and the structuring of domination relationships (Dubois 14).

\section{The Social Workers: Origins and Motivations}

Angico is the destination for the region's youth in their search for higher education. The Social Work undergraduate degree is offered by one of the city's handful of private colleges (neither 
of the two public institutions offer the degree), which graduates about 100 students per year. Social Work studies attract mostly young women from the lower-middle class (although separated by a large social gap from Bolsa Família target families), seeking socio-economic ascension through employment in public social assistance offices. This is one of the very few sources of employment for social workers, and the jobs pay more than any other that they could access without their degree. This means accepting working conditions that are far from ideal: None of the social workers I interviewed ever had a permanent contract - a stability expected when entering public service ${ }^{7}$ — which meant they had no employment protection or career plan. Since there are a limited number of positions available, and there are no mandatory selection parameters, these positions are usually occupied by people who have personal contacts within the City Hall. The smaller the municipality, the fewer positions there are available and, thus, the more important this personal network becomes. In larger cities like Angico, personal networks do not always determine access to employment, but they still play a major role in access to higher positions, which are, in consequence, occupied largely by individuals from higher classes. For the individuals who do not belong to these classes, and aim to achieve higher positions, compliance is expected, which fits in with their aspirations of social ascension.

Such a situation also affects interactions between social workers and beneficiaries, interactions that are permeated by symbolic class boundaries. It was in social workers' appearance that I first noticed signs of such boundaries, the most visible being clothing, since social workers and senior officials are not obliged to use uniforms. Social workers (who are nearly always women) often wear high heels and brand clothing and handbags; they make regular use of makeup and straighten their hair, wear fancy accessories, such as big earrings and gold bracelets, and have iPhones - all of which are unattainable, or reserved for special occasions, for beneficiaries. I never observed social workers making any effort to remove these distinctive signs, except when they felt unsafe making a house visit. Furthermore, social workers and beneficiaries do not live in the same neighborhoods nor do they frequent the same places. Over the three years of my visits to Angico I never heard of a social worker in the social assistance office nor a member of their family, who had ever received social assistance benefits.

The class differences between these two groups should also be understood as an intentional differentiation strategy. For a social worker, being a public employee is a sign of status, representing social ascension for the (lower) middle class from which the majority come. Because of their university education and their position at work, the workplace becomes a place to reaffirm their difference from beneficiaries and from lower-level staff.

\section{The Vicious Circle of Misinformation}

The relationship between social workers and beneficiaries is greatly influenced by representations of the poor that affect how they make use of the Bolsa Família's bureaucratic

\footnotetext{
${ }^{7}$ To become a public officer in Brazil and thus enjoy a lifetime stability on the job, applicants must go through a concurso público, a competitive and neutral selection process usually based on written exams that are externally controlled. Besides becoming a concursado, other types of employment ties can offer fair protection to employees, such as estatutários or celetistas. None of my interviewees had those types of contracts, which is still the case for $53.9 \%$ of workers in municipal social assistance offices in Brazil (Brasil 8).
} 


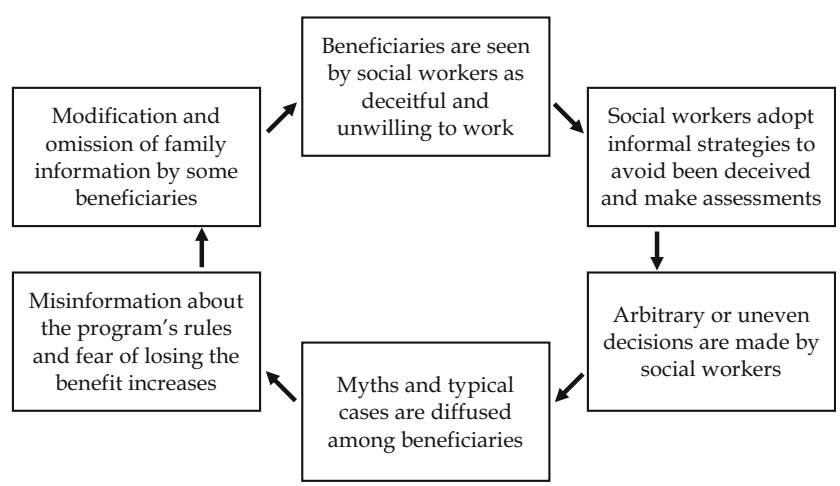

Fig. 1 A Vicious Circle: Representations of Poverty and Misinformation Within the Bolsa Família Program

procedures. The result of such process is the generation of a vicious circle (Fig. 1), which reinforces the intentional or unintentional spread of false or incorrect information, and the representation of the beneficiaries as deceitful, and frames the program as impossible to be understood.

As this is a circle, there is no starting point. I will, however, start with social workers' views on the program and its beneficiaries, as this was the main focus of my ethnographic observations. It should be noted that the six steps of the vicious circle are a simplification rather than an exhaustive model, and there may certainly be other influencing factors.

\section{Social Workers' Views on Beneficiaries}

Following Hasenfeld et al. (24), I believe that the more concrete the analyses of the politics of social policies' implementation are, and the more focused they are on families' receipt of services, "the more important it becomes to take into account ideologies of citizenship rights and obligations" $(1987,395)$. In this context, I turn first to the images social workers have of beneficiaries and the Bolsa Família. Many of the social workers I interviewed portrayed people in poverty as lazy and deceitful, always trying to take advantage of the generous state. Throughout the fieldwork, only one social worker (Márcia, 28) stood out as not fully sharing these representations, although she did not openly share her beliefs with her colleagues.

Such representations were reinforced by myths that are common in narratives of poverty. The most fundamental of them, shared by all the social workers, was that a great many of the BFP beneficiaries decline work offers in order to keep the benefits. Even when explicitly asked if this would happen when formal jobs were available (which would pay the minimum wage while the BFP benefits pay approximately a quarter of that), the interviewees would answer in the positive, attesting that they had heard of such cases. Often referred to as the "laziness effect" (efeito-preguiça) in Brazil, this hypothesis has systematically been proven to be false (de Oliveira and Soares 45). The view is expressed in two criticisms of the program: the absence of a maximum duration for the reception of benefits, and the fact that beneficiaries are not obliged to search for work. These perceptions can be better analyzed through the following excerpt:

I'm sure if the Bolsa Família had a fixed term, for example three or five years, I don't know, people would go in thinking, "I have that time to change my life. The benefit will help me and, in this period, I have to do everything I can to get out of poverty." Isn't that 
why the Bolsa Família was created? So people can get out of poverty? Like, "this is the opportunity of my life: I'm going to earn money like this, for free, and all I have to do is use it to get out of this situation." I really think [the program] can help, but for that to happen people have to really make use of it and give it their all. It is not for nothing that one receives it. It's with a commitment to change one's life. (Social worker Fernanda, 23)

What we can take from this discourse is a belief that, with the help of the Bolsa Família, beneficiaries can leave poverty behind as long as they put effort into it. The fact that social workers do not observe that occurring often enough "proves" that these families are not trying hard enough, and underscores the belief that a maximum enrollment duration in the program could give the necessary incentive to change that. Another social worker, Joana, 26, suggested that at the end of such a period an assessment could be carried out to "renew the contract," "if the family really needs [the benefit]." As a consequence, social workers avoid framing the BFP as a "right" in their interactions with the beneficiaries. Instead, they stress precisely the opposite, as another social worker Alana, 31, explained to me: "I'm a social worker and I think we need to help those in need, but ideally it's not for the rest of their lives. So I tell [beneficiaries] that... I try to get them out of the idea that the BFP would be there forever, that you can't depend on it forever, that the best thing is to find a job to be independent."

It became clear that social workers believed the Bolsa Família could also encourage beneficiaries to remain poor, since the benefit received allowed them to reach an acceptable standard of living. Recipients would thus tend not to make an effort to find work that would increase their income and render them ineligible for the program. By believing that poverty in itself should not be a reason for assistance, it is evident that these social workers see the poor as exclusively responsible for the situation they are in - and this is a widespread perception regarding people living in poverty (Krumer-Nevo and Benjamin 34). Such narratives are also widespread in other Brazilian contexts: Analyzing how residents of rich neighborhoods in São Paulo represent the poor, and how these representations are used to justify their segregation practices, Paugam et al. (47) identified a strong naturalization of poverty. Beyond noting the presence of a strong sense of meritocracy, the authors also identified veiled racism based on prejudice against immigrants from Northeast Brazil.

\section{Informal Strategies Adopted by Social Workers}

Social workers have the discretionary power to choose the information that will be taken into account in their informal assessments, which will determine the merit of the beneficiaries. Eligibility for the program is formally based on a single objective indicator: household income per person. As a result, any qualitative or subjective assessment social workers make must be integrated into this indicator through modification of the reported income, which will affect the value the beneficiary receives and, indeed, whether or not the benefit continues.

In order to assess a given family's level of poverty, social workers employ two types of strategies: investigation techniques and the manipulation of bureaucratic procedures. The investigators employ strategies aimed at "unveiling" sensitive information that beneficiaries "tend to omit or modify." Among these, the most common were: inquiring about beneficiaries' lives among neighbors (especially in order to verify the number of household residents); comparing answers given to similar questions on different occasions; and assessing the condition of the house, its furnishings, and any other items owned. In their view, these strategies can reveal not only a fraud attempt, but also the misuse of money, judged according 
to a moral hierarchy of expenditure - which I have analyzed further elsewhere (Eiró 17). They may also request details of household expenses and compare them to the declared income. "People do not think to do all the calculations beforehand," explained Helena, 24. All this information can be used by social workers to assess what they consider "the real need" of the family. Having decided this, they find a way to integrate this subjective "qualitative assessment" in the family's (physical) file - which shows the absolute power they have over the beneficiaries.

Strategies that fall into the second group - the manipulation of bureaucratic proceduresare those such as intimidating beneficiaries by summoning them to the Bolsa Família office as a tactic to dissipate anger, rather than out of any actual need; omitting information about the program's functioning and rules; and emphasizing and exaggerating the legal consequences that one might suffer if convicted of fraud. For example, each beneficiary must sign a declaration form testifying that the information given by the respondent is true. Social workers told me how they emphasize the juridical-legal nature of the document, especially where it says: "liable of criminal and civil prosecution as a result of committed frauds." Ana, 25, for example, said, "We scare them a bit" and, laughing, told me how respondents often suddenly "remember" another income source. Such distortions and omissions of information regarding the rules of the program are intended by social workers to give beneficiaries fewer opportunities to commit fraud, as is shown in the following excerpt:

I believe that almost all beneficiaries try to increase their benefits by reporting false income. They know it: if one says that one earns less, the benefit will increase. What they don't know is the finer rules for calculating the benefit's value, and that's where they get caught. I myself don't know all the finer rules of the program: it's complicated. And [as for the beneficiaries], it's better if they don't know too much, otherwise they could calculate everything beforehand and it would be more complicated to catch them in their lies. (Fernanda, 23)

Social workers thus rely on a range of informal but structured and shared strategies to creatively adapt the program (Rice 52), yet they are not deliberately aiming to undermine the program's goal. Adaptations are viewed as "fixes" to the program's flaws. Social workers believe some people truly need the benefits, such as families in extreme poverty and/or those that have a reason for not being able to work. They thus not only subjectively assess every family they encounter, but also compare them in order to establish a hierarchy of merit.

\section{Arbitrary and Uneven Decisions}

The main reason behind social workers' actions described above is that they are aware of people whom they consider as "deserving" of assistance who do not receive the BFP benefit. This is the result of the program's design. Social workers understand their role as needing to go beyond the program's guidelines, since they see them as flawed. To use the terminology developed by Paugam (48), by claiming a different role from that given to them, social workers reject the model of bureaucratic intervention predicated by the rules of the BFP, which aim to respect the dignity of the individual and reduce the stigma associated with social assistance. Social workers understand their role in the program as being closer to an individualistic intervention, on a case-by-case basis, and this justifies an intrusion into the private lives of beneficiaries and induces a moralistic relationship with the assisted families. 
They justify their practices by emphasizing the need to expose fraudulent beneficiaries. This justification has a function. According to Lipsky $(38,115)$, “[street-level bureaucrats'] conceptions of clients tend to be consistent with perspectives that exonerate them from responsibility for clients' fate," and they rely on their own experience (validity by illustration, as shown before) to support their decisions. Lipsky defends this behavior by arguing that it prevails in "proportion to the worker's need to cope with the uncertainties of decision-making and the potential consequences of those decisions." Social workers seek to cast themselves in the image of the "good bureaucrat," but also, and foremost, they justify their actions as social justice, as the following dialogue with social worker Joana (26) shows. The conversation took place after a particularly tense family visit, where the beneficiary vigorously challenged the blockage of her allowance, and Joana refused to request that the procedure be reversed:

Me: There was nothing she could say that would make you change your mind?

Joana: Of course not! [laughing] What kind of social worker would I be if I was convinced so easily? Seriously, they will say anything to have this small allowance, you would not believe the things I have already heard.

Me: I understand. It's just that it seemed to me that the lady was not very well moneywise...

Joana: But there are others worse off, that's what you must have in mind. I'm not saying she did not need it, it's just that you have to make a decision and stick to it. If when we come to the house and we see old stuff, the house in poor condition and so on, and we change our minds each time... there would not be enough allowances for all those who come to ask.

Such a justification helps to explain social workers' apparent conflict of identities, torn as they are between their role to help the poor, and their subscription to dominant representations of poverty widespread within higher socio-economic classes. The first of these identities is highlighted by their discourse when encountering critical poverty situations. Their empathy is reserved for those facing extreme situations, those "who really need it," "who have suffered much," "who try to fight against life hazards." Other situations, those less critical, are seen through the class lenses, and a stigmatizing discourse of people in poverty is evoked. According to Jilke and Tummers (31), such a discourse is pivotal in perceptions of deservingness among school teachers in the United States. In their study, the authors found that "needed deservingness" is the most effective in determining the direction of teachers' efforts: Teachers prioritize students they see as needing the most, including members of minority groups.

Bolsa Família's limited resources and the number of people on the waiting list are used to justify the coexistence of both behaviors, since they must "make room" for the "truly poor people" who are currently not receiving the benefit. Social workers' work thus becomes critical to the achievement of the program's goals, and they will be as strict as possible when it comes to finding out who is "wrongly receiving the benefit." The distinction between "deserving" and "undeserving" poor allows social workers to justify their client processing techniques - how they categorize (potential) beneficiaries - and enables them to avoid a moral and personal commitment to the people they meet. Such a situation is not new. As far back as Roth (53), in his study on hospital emergency services, found that this type of organizational categorization of clients had an enormous influence on the outcome of their requests - on both the nature and the scope of services they received (or were denied). 
Social workers use the discretion they enjoy to positively or negatively affect a family's benefit, selectively recognizing or ignoring information about beneficiaries (Hasenfeld 25). In Angico, the common practice among social workers was to estimate with the cardholder the household's average income. Social workers told me they "push" for a "real average value" in those cases, adding or removing sources of income accordingly and calculating an annual total to establish monthly values, which they can do to "help out" families they believe should receive higher benefits.

Social workers told me of the core characteristics they have identified as distinctive of the "deserving poor": a willingness not to depend on assistance, and making a clear effort to overcome poverty. With these conditions, the shame of being assisted is seen as a noble trait that reinforces the "right" to be assisted:

When I see a family that fights to get by, works hard, and doesn't want to depend on the

Bolsa Família, it gives me hope! I know cases of people saying, "Do you think it's time for me to unsubscribe from the Bolsa Família?" and I tell them to wait a little longer until they find a more stable job or finish paying off their debts. But it is clear that they don't want [to remain beneficiaries]. (Fernanda, 23)

It is important to stress, here, that the recognition of beneficiaries' rights was continuously mentioned by social workers in the definition of their work. However, the ideal of social assistance as an instrument for the practical realization of social rights is masked by the desire to identify the program's fraudsters in order to guarantee the rights of the "deserving poor." This discrepancy between implementation practices and policy goals can be understood as the result of the three dimensions, as proposed Van Meter and Van Horn (63): the extent to which the policy deviates from previous policies, the amount of organizational change that is required, and the degree of conflict or consensus over its objectives.

Although the strategies employed are shared among them and taught to new members of the group, they remain relatively individual, as are the judgments of families' merit to be assisted, and the qualitative assessment conducted. Since these are always informal, unregulated strategies, decisions can only be inconsistent and partisan. In addition to the unpredictability of the outcomes generated by these practices, we must consider that this decisionmaking also depends on the ability of beneficiaries to "convince" social workers of their need. Even those in the program's target profile feel compelled to make an effort to be worthy of assistance, as will become clearer in the following section, where I turn to beneficiaries' points of view.

\section{The Diffusion of Myths and Typical Cases}

From the point of view of the beneficiaries, the Bolsa Família makes "mistakes" and "errors" constantly. The flaws in the system include malfunctions, inequities, and random decisions. For them, the distinction between errors made by the program or its agents is not always clear. While it is evident to them that social workers' assessments are crucial for the allocation of benefits, in many cases when they inquire about "errors" in their benefits, social workers themselves blame "the system" without providing further detail.

Beneficiaries thus create their own explanations to give meaning to how the BFP functions. Confronted with the effects of random or unequal bureaucratic procedures, and unable to explain them, beneficiaries contribute to the spread of myths about the program. The following excerpt is typical of what respondents told me: 
Many people have their benefit cut [blocked or canceled] without knowing what the problem is. Some people say it was the mayor who stole the benefits, but I don't think so, I find him honest. I think that the Bolsa Família is cut off so that politicians can steal at other levels. But with me, I think it was because of a problem I had with a girl who works [in the BFP office]. It's something personal, but I think she did something... (Interview 28)

This sheds light on the misinformation regarding the program among beneficiaries who connect negative outcomes to corruption and to personal relationships with bureaucrats, rather than to the program's rules, which could cause the blockage of benefit. How the amount of the benefit is calculated is also subject to speculation on the part of the beneficiaries. Their own cases were always compared with others, and it was not uncommon for them to know not only the situation of several of their neighbors' benefits, but also the specific values. Recipients put together their knowledge of cases and the explanations they receive to formulate hypotheses about how the program works. In this way they "co-produce" meanings and definitions that are understandable for all (Weller 65). The formulation of these hypotheses is part of a process of rationalizing what one cannot understand, even if this means justifying a classificatory system that works against one's interest. The Bolsa Família staff also contribute to this process, as they, too, have only a limited knowledge of the program's rules. Several times social workers asked me to check their own hypotheses as they were not sure of the validity of their explanations - but this never stopped them from disseminating them. As a result, speculation was rife, and myths were widespread.

\section{Misinformation and Fear Among Beneficiaries}

The dissemination of myths and misconceptions about how the program works have two main effects: increased ignorance of its rules, and the generation of fear of losing the benefit among beneficiaries. The first effect is self-explanatory: These myths have great legitimacy among beneficiaries because they are based on observations of neighbors' cases or are disseminated by BFP agents. The increasing complexity of the program over the years has led to the use of simplified explanations to make sense of how it works. Lack of knowledge of the rules is unsurprising (Hevia de la Jara 26, also observed this). When facing difficulties with their allocations, beneficiaries generally did not understand what had happened. Research conducted by the MDS suggests that this is widespread in Brazil: Only 29.6\% of canceled benefits in 2010 were caused by an increase in a family's income (SAGI 54). Other main reasons were: lack of interest motivated by complications of bureaucracy; disinformation; and failure to comply with bureaucratic requirements due to health, transport, or administrative barriers. In Angico, 24 out of the 35 beneficiaries I interviewed experienced unexplained problems with their benefits.

In addition, almost all of the beneficiaries interviewed knew of families who had lost their benefits for no apparent reason and were therefore also afraid of being "victims" of such "errors" or "injustices." This was evident during the encounters I observed with social workers, where the majority of beneficiaries showed signs of stress. They explained to me that they did not know what to tell the social workers, and many of them reported not to "like" home visits or even "fear" them, while others said they were treated poorly by social workers. The examples used here show how the Bolsa Família and its municipal office, "the institution itself, its functioning, its hierarchy, are almost always surrounded by a veil of mystery," as 
Dubois $(15,118)$ notes regarding welfare offices in France. In Dubois's view, the lack of knowledge of the mechanisms of social assistance perpetuates the inequality of the relationship between users and bureaucrats.

\section{The Risk of Information Manipulation}

In this context, the visit of a social worker, or being interviewed by one in the BFP office, is stressful for beneficiaries. They know they need to pull together all the information they have and then decide what to answer, aiming at proving their poverty. Social workers know that beneficiaries do not know how the program works, and they are in a position to give out inaccurate information that will be prejudicial to the beneficiary. Social workers correct those they believe to be committing an "honest mistake," who gladly — and usually relievedcorrect the mistake. However, and again, the line that separates an honest mistake from a fraud attempt is not clear.

In my interviews with beneficiaries, this topic was not directly addressed. I did not want to jeopardize the trust they had in me by asking whether they had ever lied to a social worker. However, once we had established the beneficiary's feelings of insecurity, their fear of interactions with social workers, and their lack of knowledge about the program - which was consistent among all my respondents - it was not difficult to see and understand why they may have changed or omitted the information they gave to social workers. Many beneficiaries said that they did not know what to tell social workers, "what they wanted to know" and, during the house visits I was present at, it was common for beneficiaries to change answers when social workers repeated their questions more aggressively.

The image of the Bolsa Família among its beneficiaries is undoubtedly plural and complex. The discourse on their "rights" and the efforts made to accredit their claims are integrated into one reality: They must prove not only that they have the right to benefit from the program, but also that they deserve to. If they feel that their eligibility for the program can be questioned - if they fail to persuade social workers (whom the majority of beneficiaries view as having prejudices against them) of their eligibility - their only recourse is to exaggerate or omit information that could help their course.

\section{Beneficiaries' Attitudes Towards Bureaucratic Problems}

The vicious circle I have described has a direct impact on beneficiaries' attitudes to the Bolsa Família Program. The most notable of them is a widespread perception of the need to conform. One beneficiary (Interview 5) described how she had had her allocation blocked for months and, after receiving an explanation from a social worker that did not make sense to her, she decided not to go back to the BFP office. Although she was convinced that her household fit the program's targeted profile, she chose to wait, believing that over time the benefit would resume. Her decision illustrates a fundamental feature of beneficiaries' views of the program: the sense that uncertainty, fate, or chance rule how benefits are disbursed. For some, trying to fix problems might risk its complete cancellation, as the following dialogue reveals:

Me: Have you ever had problems with your benefit?

Beneficiary: My benefit has been blocked for three months now... but I don't know 
why. That's what it says on the receipt that comes out of the ATM. I try every month to see if the situation is resolved, but not yet.

Me: Have you thought about going to the Bolsa Família [office] to hear what they have to say?

Beneficiary: Yes, but I'd rather not go... I think it's better to leave it like that. There are people who go there and come back with nothing [a permanent cancellation of benefits]. It's better not to risk it.

Me: What do you mean? Are you worried that they might discover other errors in your benefit?

Beneficiary: There are no mistakes with me, I do everything right, all the conditions, everything is fine. That's because you never know. If we're there, they can always find reasons to block my benefit. It's just that it's better to wait. Everything's going to be okay (Interview 22).

This misunderstanding may be due to different reasons, such as lack of knowledge on the part of the beneficiary herself, a sense of shame explaining the reasons for the block to her acquaintances, or a lack of explanation by the BFP's agents. However, the quantity and robustness of stories I heard from different beneficiaries pointing in the same direction suggest the existence of a myth that affects the behavior of the beneficiaries to the point that fear stops them from verifying a possible error to solve the problem. Beneficiaries seemed to yield to compliance and, on the few occasions they try to solve problems, they will take any explanation, since they have no other reference point. They see cases around them of people losing their benefit without apparent reason. Similar to what other authors have found (i.e., Ávila 3; Tebet 62), they are not sure what is going to happen with their own benefit, and they feel somehow lucky to still have one, even if it is mysteriously reduced or blocked for months.

If things were working sufficiently well, over half the beneficiaries I interviewed said they would not go to the Bolsa Família office as they were afraid that this might trigger the benefit's permanent cancellation. Another case (Interview 19) provided insight into this matter: When the beneficiary went to the BFP office to find out why her benefit had been reduced, she was told at the front desk: "It is better to do nothing. Changing [family data] could complicate everything." She did as she was told.

It is noteworthy that some interviewees formulated a justification for their right to the Bolsa Família based on the right to a dignified life. However, I found that the most prominent feeling regarding the program was insecurity about its continuity, which raises questions about how the program is seen as a "help" rather than a "right." All my interviewees manifested some degree of fear or incomprehension regarding how the program functioned, even those who saw it as a "right": "It is our right, but I do not understand why there are people who lose [the benefit], some people do not need it, and still receive it. That is just wrong" (Interview 26). At the same time, beneficiaries are resigned to the fact that they will not understand its "mysteries." Another respondent (Interview 23), for instance, saw the loss of her benefit as a gross injustice as it had hugely negative impact on her life. Nevertheless, in her words, "that's the way it is" [mas é assim mesmo].

This compliance relates to the impressions beneficiaries have regarding the continuity of the program. Some told me they could not count on the benefit because they did not know when it

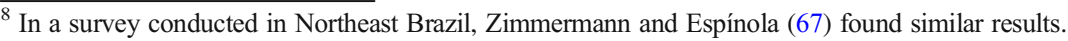


might end. One senior official at the MDS told me about a beneficiary he had encountered during fieldwork who, every month, would go to the ATM to withdraw her benefit, expecting it to have ended. When the money came out, she would say out loud: "Thank God, it worked out this month." I myself witnessed a social worker telling a beneficiary that the program was designed to have "a beginning, middle, and end, and that it [had] been prolonged momentarily, but can end at any moment."

As I have explained, beneficiaries have six months to contest blocks to their benefits, which lead to the permanent cancellation. Nevertheless, the possibility of such contestation presupposes a combination of several factors: immediate notification to the families, the availability of the head of the family to go to the Bolsa Família officewhich presupposes an understanding that the block is incorrect, that they can afford to travel there, and that this action might have a positive effect - and the acceptance of the request by the BFP officers. In his study, Dubois also acknowledges that beneficiaries can be active rather than passive, that there is the possibility of "sliding into [the system's] loopholes and making the peaceful order of the institution problematic" (Dubois 15,40 ). While I do believe that such behavior likely exists, I can only conclude that these are rare and isolated cases.

\section{Discussion and Conclusions}

This article has shown how each encounter between street-level bureaucrat and client represents an instance of policy delivery, which is shaped by agents' conceptions of their work and of their clients, determining "in a concrete way the form and substance of citizens' rights" (Hasenfeld et al. 24, 398). These conceptions integrate a vision of society and the material limitations social workers face in daily activities when delivering those policies. The practices that derive from this collective process "are maintained even as they contribute to the distortion of the service ideal" (Lipsky 38, xv). The vicious circle analyzed here allows us to predict that the more aggressive the strategies used by social workers to disclose information, the greater the insecurity experienced by beneficiaries regarding the continuity of their benefits, and the greater the incentive they will have to modify or omit information determining their access to the Bolsa Família. If social workers believe that attempts to deceive them are increasing, their vision of beneficiaries as fraudulent is reinforced, justifying the need for more invasive and aggressive strategies.

In the cases I have presented, social workers fiercely contest for whom the Bolsa Família is supposed to be a social right, but rarely challenge its existence or the duty of the state to help the poor. They do not deliberately undermine the BFP's goals, but "creatively adapt" (Rice 52) the program's practices to better fit their own visions of social assistance. Misinformation about the program, beyond being a result of its increasing complexity, is deliberately fed to beneficiaries by social workers in order to give fewer benefits to those who may be deceiving them. By integrating representations of poverty into their activities and classifying some as "undeserving" of social assistance, social workers contribute to creating an atmosphere of insecurity and fearbased compliance among beneficiaries, while simultaneously putting at risk the consolidation of social rights that even legally fragile policies such as the Bolsa Família Program could achieve. 
While many studies have focused on regulatory practices regarding recipients' behavior, which fall disproportionally on the shoulders of women, ${ }^{9}$ I have focused on judgments of poverty and the merits of assistance. Although I do not characterize the interactions described here as consequence of the gender of the recipients and social workers - all of whom were women in my research - it is clear that female recipients are the main target of social workers' informal evaluations and, as such, these relationships are based on conflicting notions of moral norms, which create what Serre (57) sees as "contradictory dictates for women." Focusing specifically on the gender dimension of the relationship between female social workers and poor women in France, Serre shows that, by putting these women of different social backgrounds in intense contact, such policies create "compassion traps: while gender proximity fosters benevolence, perceived nonconformist reactions to the requirement of autonomy may lead to distance and recourse to the justice system as a tool of constraint" $(2017,8)$. The same is true for race, as the social workers in my research location were mostly white, while beneficiaries were predominantly black or brown. BFP beneficiaries are thus the ones that, first and foremost, have their citizenship subjected to class and race prejudices, and feel the stigma towards the poor in a highly unequal society.

The results I have presented here raise questions regarding the nature of the program. There is an abundance of critics of the program's conditional and means-tested aspects, but most empirical research to date has not found any indication that these aspects impact on perceptions of it. Results from my own research, that I have not presented in this article, also point to overwhelmingly positive attitudes towards the program. I do not contest that the Bolsa Família's main features - conditional and means-tested benefits for applicants-allow the generation of citizenship norms, and I do not believe they are contrary to democratic values. However, based on my empirical research, I offer an argument of a different nature: the way these features are perceived by local agents and how they are integrated in their work has the potential to limit the citizenship expansion aims of the program.

As with other street-level bureaucracies, local agents must face precarious conditions of work (i.e., perceived resource scarcity and an overload of cases). Based on their perceptions "on the ground," they feel compelled to "better apply" the resources. Their work ethic of helping those most in need, combined with the fact that they see families in urgent situations not being assisted, drive them to use their discretion and "make room" in the program. By not providing universal coverage (even if the program is close to that), and by creating mechanisms for family checking, the Bolsa Família sets up social workers $^{10}$ : driven to perform their work well, they are at risk of compromising its very core objective of promoting social citizenship.

So why have other studies not found similar results? Based on my fieldwork, I have two interrelated hypotheses. The first is that the program's fragile legal status is its most overlooked feature, and we should be empirically critical of the usage of the word "right" by beneficiaries. The second is that not enough focus is given to the social workers themselves: it is given, instead, to beneficiaries' perceptions of them and of the program. In the interviews I conducted with beneficiaries this was not a subject that came up easily. I believe this is because the positive outcomes of the program outweigh the negative aspects (for both beneficiaries and

\footnotetext{
${ }^{9}$ Regarding the experience of behavioral "coercion" regarding motherhood, see Nagels (43), Molyneux (42) and Piccoli (49); Gil-Garcia (2015) analyzed the "invasive forms of contraceptive surveillance," and Cookson (11) and Tebet (62), the overburden of women's responsibilities and unpaid work.

${ }^{10}$ I thank one of the reviewers of Qualitative Sociology for suggesting the most suitable term "setting up" for this context.
} 
researchers) and are thus more visible. Furthermore, as I hope is clear in this article, these tensions arise not from the program itself, and are thus not "consequences" of it, but are rather the reproduction of normalized class relations.

Zooming in on social workers, extensive research has shown how they integrate expectations of gender, race, and class into their work, and resonates with the results presented here. Reich (30) has shown how decisions regarding child welfare taken by social workers are dependent on the performance of deference to their assessments in the name of the state. The expectation of how such interventions will be received, which are related to perceived deservingness, is connected to normative beliefs of race, class, and gender. Arriving at a similar conclusion to my view of the existence of a vicious circle, Reich sees how this system can retro-feed itself, since "for parents who have not experienced state intervention as coercive, restrictive, or punitive, deference is easier" $(2005,110)$.

In her historical analysis of United States immigration policies (1890-1940), Fox (20) revels how social workers viewed European immigrants differently to other ethnic claimants to welfare, and facilitated their access to benefits. She argues that social workers were not merely street-level bureaucrats adapting policies, they also made "sustained efforts to convince local and national legislators and the broader public of their 'expert' opinions" $(2012,15)$. By doing so, these social workers could create de facto different welfare "worlds" based on ethnic differences. Similarly, analyzing the experience of waiting in an Argentinian welfare office, Auyero (2) shows how, by making welfare beneficiaries wait, the state reaffirms its power, requiring compliance and deference from poor citizens. The obscure procedures disguised as the "system's workings" lead to uncertainty and resignation.

What these studies have in common is that they show how, intentionally or not, social workers participate in reproducing social inequalities, not only in the welfare system, but through it, in society at large. The underlying question these studies try to answer is whether social workers operate independently of the contextual forces, or if they are, to a certain extent, controlled by the state. This article sheds light on this issue by focusing on the gap between the institutional context and public perceptions. The Bolsa Família is the most progressive form of large-scale social assistance Brazil has ever had, especially due to its emphasis on autodeclaration and the direct cash transfer intended to be freely used by the recipient. Moreover, social workers form a particularly progressive segment of bureaucracy that has had an important historical role in the development of this and other social programs and welfare laws in the country. Nevertheless, a paradox persists in the work of the individuals charged with the implementation of this program: Although social workers largely support the program, and consider it to be necessary, its design does not live up to public perceptions of how state aid should be provided. Social workers, as I have shown, are far from immune to factors such as institutional and political contexts, public views, and poverty prejudices, when adapting the implementation of the welfare program - and their actions are not without consequences.

It is noteworthy that the research on which this article is based was conducted before the peak of the political and economic crisis that has inflicted Brazil in the last few years, leading to budgetary cuts in the program. In 2018, the far-right politician Jair Bolsonaro was elected president and, since taking office, he has promised to undertake severe auditing of the program in order to exclude "irregular" beneficiaries. As beneficiaries were already voicing concerns about the future of the program in 2014, these recent events should be seen in light of the results presented in this article-and the everincreasing insecurity beneficiaries must be suffering. 
Acknowledgements This article originates from my PhD thesis in sociology, defended at the École des hautes études en sciences sociales (EHESS - Paris) in 2017. I would like to thank Serge Paugam, Marcel Bursztyn, Martijn Koster, Laurent Henry, and Linda Haapajärvi for their valuable comments on former versions of this article. I also thank Roberto Pires and the IPI - Inequalities and Policy Implementation Research Network for support and inspiration. This project has received funding from the European Research Council (ERC) under the European Union's Horizon 2020 research and innovation programme (grant agreement No. 679614). It also benefitted from the support of the CAPES Foundation, Brazilian Education Ministry (PhD scholarship process number 99999.001728/2013-00).

\section{Appendix}

\section{Social Workers' Biographical Note}

Participants in the research, ordered alphabetically: name (fictitious), age (when first met), origin, location of social work studies undertaken, job description, date of first meeting.

Alana, 31, originally from Angico, studied in Angico. CRAS employee. First met in October 2014.

Aline, 38, originally from Angico, studied in Fortaleza. CRAS Coordinator between 2012 and, and coordinator of the local BFP office in 2016. First met in October 2014.

Ana, 25, originally from Angico, studied in Angico. BFP employee from 2014 to 2015 (first job). First met in October 2014.

Bruna, 23, originally from Angico, studied in Angico. CRAS employee since January 2015 (first job). First met in November 2015.

Carla, 30, originally from Angico, studied in Angico. CRAS employee since January 2014. First met in October 2014.

Denise, 28, originally from a neighboring municipality of Angico, studied in Angico. BFP employee since 2013 and previously employed at her hometown's BFP office for two years. First met in October 2013.

Fernanda, 23, originally from Angico, studied in Angico. BFP employee since 2014 (first job). First met in October 2014.

Helena, 24, originally from Angico, studied in Angico. BFP employee since 2013 (first job). First met in October 2013.

Joana, 26, originally from a neighboring municipality of Angico, studied in Angico. BFP employee from 2011 to 2014, and CRAS employee from 2014 to 2015. First met in August 2013.

Laura, 35, originally from Angico, studied in Angico. CRAS employee since January 2013, after having worked in several welfare offices in neighboring municipalities. First met in October 2014.

Mara, 40, originally from Fortaleza (capital of Ceará), studied in Fortaleza. High-level coordinator at the Angico's welfare office. Former BFP coordinator of a neighboring municipality. First met in August 2013.

Márcia, 28, originally from a neighboring municipality of Angico, studied in Angico. BFP employee in a small neighboring municipality, then at the CRAS in Angico from 2014 to 2015. First met in October 2014.

Milena, 25, originally from Angico, studied in Angico. CRAS employee since November 2014. First met in October 2015. 
Natalia, 28, originally from a neighboring municipality of Angico, studied in Angico. CRAS employee CRAS since January 2015, and previously worked in other units of the welfare office in Angico. First met in November 2015.

Olivia, about 55, from Angico, no higher education. BFP coordinator from 2012 to 2016. First met in August 2013.

Paula, 23, originally from Angico, studied in Angico. BFP employee from 2014 to 2015, and CRAS employee since August 2015. First met in October 2014.

Roberta, 25, originally from a neighboring municipality of Angico, studied in Angico. CRAS employee in 2014 (first job). First met in October 2014.

Sofia, 24, originally from Angico, studied in Angico. CRAS employee since 2014 (first job). First met in October 2014.

\section{Interviews with Bolsa Família Program Beneficiaries}

Data ordered by date of interview (at the end of line): occupation, age, number of children, and data of enrollment in the Bolsa Família.

1. Housewife, 35, 2 children, beneficiary since 2007. October 2014.

2. Housewife, 32, 3 children, beneficiary since 2007. October 2014.

3. Domestic worker, 28, 3 children, beneficiary since 2007. October 2014.

4. Informal domestic worker, 30, 2 children, beneficiary since 2010. October 2014.

5. Domestic worker (occasional), 40, 2 children, beneficiary since 2005. October 2014.

6. Housewife, 24, 3 children, beneficiary since 2010. October 2014.

7. Housewife, 32, 1 child, beneficiary since 2007. October 2014.

8. Housewife, 30, 2 children, beneficiary since 2007. October 2014.

9. Domestic worker, 27, 2 children, beneficiary since 2007. October 2014.

10. Informal domestic worker, 27, 3 children, beneficiary since 2007. October 2014.

11. Domestic worker (occasional), 43, 2 children, beneficiary since 2005. October 2014.

12. Housewife, 22, 2 children, beneficiary since 2010. October 2014.

13. Housewife, 27, 2 children, beneficiary since 2006. October 2014.

14. Housewife, 30, 2 children, beneficiary since 2007. October 2014.

15. Housewife, 28, 3 children, beneficiary since 2009. November 2014.

16. Domestic worker, 29, 3 children, beneficiary since 2013. November 2014.

17. Informal worker (occasional), 30, 3 children, beneficiary since 2005. October 2015.

18. Housewife, 28, 2 children, beneficiary since 2007. October 2015.

19. Informal worker (occasional), 38, 3 children, beneficiary since 2006. October 2015.

20. Housewife, 35, 3 children, beneficiary since 2007. October 2015.

21. Domestic worker, 24, 2 children, beneficiary since 2009. October 2015.

22. Informal domestic worker, 29, 2 children, beneficiary since 2013. October 2015.

23. Informal worker (occasional), 45, 4 children, beneficiary from 2004 to 2014. October 2015.

24. Informal domestic worker, 26, 2 children, beneficiary since 2010. October 2015.

25. Domestic worker, 31, 1 child, beneficiary since 2012. October 2015.

26. Domestic worker, 25, 2 children, beneficiary since 2011. October 2015.

27. Informal domestic worker, 28, 4 children, beneficiary since 2010. October 2015

28. Informal worker (occasional), 33, 3 children, beneficiary since 2008. October 2015.

29. Domestic worker, 27, 1 child, beneficiary since 2010. October 2015. 
30. Informal worker (occasional), 45, 4 children, beneficiary since 2005. October 2015.

31. Informal worker (occasional), 23, 2 children, beneficiary since 2011. October 2015.

32. Housewife, 31, 3 children, beneficiary since 2006. October 2015.

33. Housewife, 24, 1 child, beneficiary since 2012. October 2015.

34. Informal domestic worker, 23, 2 children, beneficiary since 2011. October 2015.

35. Informal domestic worker, 33, 3 children, beneficiary since 2008. October 2015.

Open Access This article is distributed under the terms of the Creative Commons Attribution 4.0 International License (http://creativecommons.org/licenses/by/4.0/), which permits unrestricted use, distribution, and reproduction in any medium, provided you give appropriate credit to the original author(s) and the source, provide a link to the Creative Commons license, and indicate if changes were made.

\section{References}

de Almeida, Maria H.T. 1995. Federalismo e políticas sociais. RBCS 28 (10): 88-108.

Auyero, Javier. 2011. Patients of the state: An ethnographic account of poor people's waiting. Latin American Research Review 46 (1): 5-29.

Ávila, Milene P. 2013. Que pensam as beneficiárias do Bolsa Família? Política e Trabalho 38 (1): $105-122$.

Barrientos, Armando. 2013. The rise of social assistance in Brazil. Development and Change 44 (4): 887-910.

Bichir, Renata M. 2011. Mecanismos federais de coordenação de políticas sociais e capacidades institucionais locais: O caso do Programa Bolsa Família. PhD thesis (Political Science) - IESP/UERJ, Rio de Janeiro.

Bohn, Simone R. 2011. Social policy and vote in Brazil: Bolsa Família and the shifts in Lula's electoral base. Latin American Research Review 46 (1): 54-79.

Bourdieu, Pierre. 1989. Social space and symbolic power. Sociological Theory 7 (1): 14-25. https://doi. org/10.2307/202060.

Brasil. 2015. Censo SUAS 2014: Análise dos componentes sistêmicos da política nacional de assistência social. Brasília: Ministério do Desenvolvimento Social e Combate à Fome.

Caillé, Allain (ed). 1996. Vers un revenu minimum inconditionnel ? La Revue du MAUSS 7 (1).

Campello, Tereza, and Marcelo C. Neri. 2013. Programa Bolsa Família: Uma década de inclusão e cidadania. Brasília: IPEA.

Cookson, Tara Patricia. 2018. Unjust conditions: Women's work and the hidden cost of cash transfer programs. Oakland, California: University of California Press.

de Brauw, Alan, Daniel O. Gilligan, John F. Hoddinott, and Shalini Roy. 2014. The impact of Bolsa Família on women's decision-making power. World Development 59: 487-504.

Desforges, Luke, Rhys Jones, and Mike Woods. 2005. New geographies of citizenship. Citizenship Studies 9 (5): 439-451. https://doi.org/10.1080/13621020500301213.

Dubois, Vincent. 2009. Towards a critical policy ethnography: Lessons from fieldwork on welfare control in France. Critical Policy Studies 3 (2): 221-239. https://doi.org/10.1080/19460170903385684.

Dubois, Vincent. 2015. La vie au guichet: Administrer la misère. Paris: Éditions Points.

Eiró, Flávio. 2017. "La régulation familialiste de la pauvreté: Le cas du Programme Bolsa Família dans la région Nordeste du Brésil.” PhD diss., École des hautes études en sciences sociale. doi:https://doi.org/10.31235/osf. io/srukg.

Eiró, Flávio. 2019. A "boa implementação” do Programa Bolsa Família: A interação entre assistentes sociais e beneficiárias para além das regras burocráticas. In Implementando desigualdades: Reprodução de desigualdades na implementação de políticas públicas, ed. Roberto Pires, 617-635. Rio de Janeiro: Ipea.

Evans, Tony, and John Harris. 2004. Street-level bureaucracy, social work and the (exaggerated) death of discretion. British Journal of Social Work 34 (6): 871-895. https://doi.org/10.1093/bjsw/bch106.

Fenwick, Tracy B. 2009. Avoiding governors: The success of Bolsa Família. Latin American Research Review 44 (1): $1-30$.

Fox, Cybelle. 2012. Three worlds of relief: Race, immigration, and the American welfare state from the progressive era to the New Deal. Princeton: Princeton University Press.

Hall, Anthony. 2006. From Fome zero to Bolsa Família: Social policies and poverty alleviation under Lula. Journal of Latin American Studies 38 (4): 689-709. 
Hall, Anthony. 2013. Political dimensions of social protection in Brazil. In Social protection, economic growth and social change: Goals, issues and trajectories in China, India, Brazil and South Africa, eds. James Midgley and David Piachaud, 166-183. Cheltenham: Edward Elgar.

Handler, Joel F. 1973. The coercive social worker: British lessons for American social services. Chicago: Rand McNally.

Hasenfeld, Yehenskel, Jane A. Rafferty, and Mayer N. Zald. 1987. The welfare state, citizenship, and bureaucratic encounters. Annual Review of Sociology 13 (1): 387-415. https://doi.org/10.1146/annurev. so.13.080187.002131.

Hasenfeld, Yehenskel. 1985. Citizens' encounters with welfare state bureaucracies. Social Service Review 59 (4): $622-635$.

Hevia de la Jara, Felipe J. 2011. Relaciones sociedad-estado, participación ciudadana y clientelismo político en programas contra la pobreza. El caso de Bolsa Familia en Brasil. América Latina Hoy Revista de Ciencias Sociales 57: 205-238.

Hunter, Wendy and Natasha B. Sugiyama. 2013. Assessing the Bolsa Família: Successes, shortcomings, and unknowns. Paper presented at the "Democratic Brazil Emergent" conference, University of Oxford and the Brazil Institute, King's College London, February 22, 2013.

Hunter, Wendy, and Natasha Borges Sugiyama. 2014. Transforming subjects into citizens: Insights from Brazil's Bolsa Família. Perspectives on Politics 12 (4): 829-845. https://doi.org/10.1017/S1537592714002151.

Hunter, Wendy. 2014. Making citizens: Brazilian social policy from Getúlio to Lula. Journal of Politics in Latin America 6 (3): 15-37.

Reich, Jennifer A. 2005. Fixing families: Parents, power, and the child welfare system. New York: Routledge.

Jilke, Sebastian, and Lars Tummers. 2018. Which clients are deserving of help? A theoretical model and experimental test. Journal of Public Administration Research and Theory 28 (2): 226-238. https://doi. org/10.1093/jopart/muy002.

Katz, Michael B. 2013. The undeserving poor: America's enduring confrontation with poverty. New York: Oxford University Press.

Koster, Martijn. 2014. Fear and intimacy: Citizenship in a Recife slum, Brazil. Ethnos 79 (2): $215-237$. https://doi.org/10.1080/00141844.2012.732955.

Krumer-Nevo, Michal, and Orly Benjamin. 2010. Critical poverty knowledge: Contesting othering and social distancing. Current Sociology 58 (5): 693-714.

Kruper, Christopher and David Nugent. 2015. State theory and Andean politics: New approaches to the study of rule. University of Pennsylvania Press.

Lavergne, Rémi F., and Bernadete Beserra. 2016. The Bolsa Familia program: Replacing politics with biopolitics. Latin American Perspectives 43 (2): 96-115.

Leao Rego, Walquiria, and Alessandro Pinzani. 2013. Vozes do Bolsa Família: Autonomia, dinheiro e cidadania. São Paulo: Editora da Unesp.

Lipsky, Michael. 1980. Street-level bureaucracy: Dilemmas of the individual in public services. New York: Russell Sage Foundation.

Lotta, Gabriela S. 2014. Agentes de implementação: Uma forma de análise de políticas públicas. Cadernos Gestão Pública e Cidadania 19 (65): 186-206.

Lund, Sarah. 2001. Bequeathing and quest. Processing personal identification papers in bureaucratic spaces (Cuzco, Peru). Social Anthropology 9 (1): 3-24.

Maynard-Moody, Steven, and Michael C. Musheno. 2003. Cops, teachers, counselors: Stories from the front lines of public service. Michigan: University of Michigan Press.

Molyneux, Maxine. 2006. Mothers at the service of the new poverty agenda: Progresa/Oportunidades, Mexico's conditional transfer programme. Social Policy and Administration 40 (4): 425-449.

Nagels, Nora. 2016. The social investment perspective, conditional cash transfer programmes and the welfare mix: Peru and Bolivia. Social Policy and Society 15 (3): 479-493. https://doi.org/10.1017 /S1474746416000105.

de Oliveira, Breynner R. 2014. A implementação do Programa Bolsa Família sob a perspectiva da condicionalidade educacional: Uma análise a partir dos agentes públicos de base. Revista do Serviço Público 65 (4): 517-544.

de Oliveira, Luis F.B., and Sergei S.D. Soares. 2012. O que se sabe sobre os efeitos das transferências de renda sobre a oferta de trabalho. Textos para discussão 1738. Rio de Janeiro: IPEA.

Osorio, Rafael G., and Sergei S.D. Soares. 2014. O Brasil sem Miséria e as mudanças no desenho do Bolsa Família. In O Brasil sem miséria, ed. Ministério do Desenvolvimento Social e Combate à Fome, 747-762. Brasília: MDS.

Paugam, Serge, Bruno Cousin, Camila Giorgetti, and Jules Naudet. 2017. Ce que les riches pensent des pauvres. Paris: Seuil. 
Paugam, Serge. 2002. La société française et ses pauvres : L'expérience du revenu minimum d'insertion. Paris: Presses Universitaires de France.

Piccoli, Emmanuelle. 2014. «Dicen que los cien soles son del Diablo»: L'interprétation apocalyptique et mythique du Programa Juntos dans les communautés Andines de Cajamarca (Pérou) et la critique populaire des programmes sociaux. Social Compass 61 (3): 328-347. https://doi.org/10.1177/0037768614535701.

Pires, Roberto R.C. 2017. Implementação de políticas públicas e reprodução de desigualdades. In Boletim de Análise Político-Institucional, 13. Brasília: Instituto de Pesquisa Econômica Aplicada.

Pires, Roberto R.C. 2009. Burocracia, discricionariedade e democracia: Alternativas para o dilema entre controle do poder administrativo e capacidade de implementação. Cadernos Gestão Pública e Cidadania 14 (54): 147-187.

Rice, Deborah. 2012. Street-level bureaucrats and the welfare state: Toward a micro-institutionalist theory of policy implementation. Administration \& Society 45 (9): 1038-1062.

Roth, Julius A. 1972. Some contingencies of the moral evaluation and control of clientele: The case of the hospital emergency service. American Journal of Sociology 77 (5): 839-856. https://doi.org/10.1086 1225227 .

SAGI, Secretaria de Avaliação e Gestão da Informação. 2014. Estudo sobre o perfil das famílias que sofreram repercussões sobre o benefício do Programa Bolsa Família em decorrência do processo de revisão cadastral. Cadernos de Estudos: Desenvolvimento Social em Debate 16: 35-38.

Sánchez-Ancochea, Diego, and Lauro Mattei. 2011. Bolsa Família, poverty and inequality: Political and economic effects in the short and long run. Global Social Policy 11 (2-3): 299-318.

Santos, Yumi G. 2014. As mulheres como pilar da construção dos programas sociais. Caderno CRH 27 (72): 479-494.

Serre, Delphine. 2017. Class and gender relations in the welfare state: The contradictory dictates of the norm of female autonomy. Social Sciences 6 (48): 1-10. https://doi.org/10.3390/socsci6020048.

Siblot, Yasmine. 2006. Faire valoir ses droits au quotidien. Les services publics dans les quartiers populaires. Paris: Presses de Sciences Po.

Spire, Alexis. 2008. Accueillir ou reconduire: Enquête sur les guichets de l'immigration. Paris: Raisons d'agir.

Sugiyama, Natasha B., and Wendy Hunter. 2013. Whither clientelism? Good governance and Brazil's Bolsa Família program. Comparative Politics 46 (1): 43-62.

Suplicy, Eduardo M. 2010. Renda e cidadania: A saída é pela porta. São Paulo: Cortez.

Tebet, Mani. 2017. Symbolic and gender boundaries among the Bolsa Familia beneficiaries. Sociology and Anthropology 5 (8): 635-644. https://doi.org/10.13189/sa.2017.050807.

Van Meter, Donald S., and Carl E. Van Horn. 1975. The policy implementation process: A conceptual framework. Administration \& Society 6 (4): 445-488. https://doi.org/10.1177/009539977500600404.

Warin, Philippe. 2003. Les relations de service, objet de recherche en sciences sociales. Pyramides - Revue du Centre d'Etudes et deRecherches en Administration Publique 7: 19-32.

Weller, Jean-Marc. 1999. L'état au guichet: Sociologie cognitive du travail et modernisation administrative des services publics. Paris: Desclée de Brouwer.

Yazbek, Maria C. 2004. Assistência social na cidade de São Paulo: A (dificil) construção do direito. São Paulo: Instituto Pólis/PUC-SP.

Zimmermann, Clóvis R., and Gepherson M. Espínola. 2015. Programas sociais no Brasil: Um estudo sobre o Programa Bolsa Família no interior do Nordeste brasileiro. Caderno CRH 28 (73): 147-164.

Publisher's Note Springer Nature remains neutral with regard to jurisdictional claims in published maps and institutional affiliations.

Flávio Eiró is a Postdoctoral Research Fellow in the Department of Anthropology and Development Studies, Radboud University. He holds a PhD (2017) in Sociology from the École des Hautes Etudes en Sciences Sociales (EHESS). He is a researcher for the European Research Council project "Participatory urban governance between democracy and clientelism: Brokers and (in)formal politics," analyzing informal politics and participation in four cities: Manchester, Medellín, Recife, and Rotterdam. His research interests include clientelism, informal politics, citizenship, social assistance, and poverty. 